\title{
PENERAPAN DAN PENINGKATAN SANITASI MAKANAN PADA PRODUKSI KERUPUK IKAN DI UD SUMBER REJEKI KELURAHAN GUNUNG ANYAR TAMBAK KOTA SURABAYA
}

\section{IMPLEMENTATION AND IMPROVEMENT OF FOOD SANITATION IN FISH CRACKERS PRODUCTION IN UD SUMBER REJEKI GUNUNG ANYAR TAMBAK VILLAGE SURABAYA CITY}

\author{
Nove Kartika Erliyanti ${ }^{1)^{*}}$, Andre Yusuf Trisna Putra ${ }^{2)}$, Ira Wikartika ${ }^{3)}$, Dika Prasetyo ${ }^{4}$, \\ Rangga Kurnia Putra ${ }^{5}$, Norizul Inayah") \\ ${ }^{1)}$ Fakultas Teknik, Universitas Pembangunan Nasional "Veteran” Jawa Timur \\ email: nove.kartika.nke.tk@upnjatim.ac.id \\ ${ }^{2)}$ Fakultas Teknik, Universitas Pembangunan Nasional "Veteran" Jawa Timur \\ email: andreyusuf.tp@upnjatim.ac.id \\ ${ }^{3)}$ Fakultas Ekonomi dan Bisnis, Universitas Pembangunan Nasional "Veteran" Jawa Timur \\ email: irawikartika@upnjatim.ac.id \\ ${ }^{4)}$ Fakultas Teknik, Universitas Pembangunan Nasional "Veteran” Jawa Timur \\ email: dikaprasetyo25.dp@gmail.com \\ ${ }^{5)}$ Fakultas Teknik, Universitas Pembangunan Nasional "Veteran" Jawa Timur \\ email: ranggkurniaputra@gmail.com \\ ${ }^{6)}$ UD Sumber Rejeki Desa Gunung Anyar Tambak Kota Surabaya
}

\begin{abstract}
ABSTRAK
Permasalahan yang terjadi pada mitra (UD Sumber Rejeki) adalah minimnya pengetahuan tentang sanitasi makanan pada produksi kerupuk ikan. Hal ini dapat terlihat dari kondisi peralatan yang digunakan dalam produksi kerupuk ikan yang belum sepenuhnya dipisahkan antara peralatan proses produksi dan peralatan rumah tangga. Kurangnya pengetahuan mitra juga ditunjukkan pada saat proses produksi belum menggunakan baju produksi (apron), topi koki, dan dalam produksi kerupuk ikan belum memenuhi kaidah atau pedoman Cara Produksi Pangan Olahan yang Baik (CPPOB). Kegiatan ini bertujuan untuk menerapkan dan meningkatkan sanitasi makanan pada produksi kerupuk ikan sesuai dengan kaidah CPPOB. Metode yang digunakan pada kegiatan ini adalah melakukan sosialisasi, pendampingan, dan edukasi tentang penerapan dan peningkatan sanitasi serta penggunaan peralatan yang sesuai dengan kaidah CPPOB. Metode lainnya adalah membantu pengadaan baju produksi (apron), topi koki, booklet yang berisikan sanitasi diri, bahan baku, peralatan, dan sanitasi ruangan. Hasil dari kegiatan ini adalah mitra sangat antusias dalam menerima materi yang disampaikan dan berkomitmen untuk menerapkan dan meningkatkan sanitasi serta penggunaan peralatan sesuai dengan kaidah CPPOB, adanya baju produksi (apron), topi koki, masker, tempat sampah, dan booklet.
\end{abstract}

Kata kunci: $C P P O B$, Manajemen produksi, Produksi kerupuk ikan, Sanitasi, UD sumber rejeki

\section{ABSTRACT}

The problem that occurs to partner (UD Sumber Rejeki) is the lack of knowledge about food sanitation in fish crackers production. This can be seen from the condition of the equipment used in the production of fish crackers that has not been completely separated between the production process equipment and household appliances. The lack of knowledge of partner is also shown when the production process does not use apron, chef's hat, and fish crackers production does not meet the rules for CPPOB. This aims to implement and improve food sanitation in fish crackers production in accordance with CPPOB principles. The method used in this activity is to conduct socialization, mentoring, and counseling on the implementation and improvement of sanitation and the use of equipment in according with 
CPPOB principles. Another method is to help procure apron, chef's hat, booklets containing personal sanitation, raw materials, equipment, and room sanitation. The results of this activity is that the partner is very enthusiastic in receiving the material presented and is committed to implementing and improving sanitation and the use of equipment in accordance with CPPOB principles, the existence of apron, chef's hat, masks, trash bins, and booklets.

Keywords: CPPOB, Fish Crackers Production, Production Management, Sanitation, UD sumber rejeki

\section{PENDAHULUAN}

Surabaya merupakan kota terbesar di provinsi Jawa Timur dan sebagai ibukota provinsi. Surabaya yang terletak di pesisir pantai utara Jawa menjadikan usaha berbasis perikanan tumbuh subur. Usaha yang bergerak pada sector perikanan terdiri dari usaha budidaya, penangkapan, hingga usaha pembuatan produksi olahan ikan seperti kerupuk, petis, dan ikan asap. Usaha penangkapan ikan air laut di Surabaya tercatat sebanyak 1879 dan usaha yang bergerak pada usaha budidaya bandeng, udang, lele, dan nila sebanyak 1249 [1].

Potensi hasil perikanan yang melimpah di Kota Surabaya menjadikan usaha pengolahan hasil perikanan tumbuh subur. Salah satu usaha pengolahan hasil perikanan di kota Surabaya adalah produksi kerupuk ikan yang tumbuh dan berkembang di wilayah pantai timur Surabaya (Pamurbaya) seperti Kecamatan Gunung Anyar, Kenjeran, dan Wonorejo. Usaha tersebut semakin meningkat dengan adanya kontribusi dari dinas terkait seperti Dinas Perindustrian Kota Surabaya dalam hal berdirinya Usaha Kecil Menengah (UKM) baru yang memproduksi kerupuk ikan [2]. Produk kerupuk ikan yang paling diminati oleh masyarakat adalah kerupuk ikan payus, kerupuk udang, dan kerupuk lele.

Salah satu UKM yang telah memproduksi kerupuk ikan adalah UD Sumber Rejeki yang dikelolah oleh Ibu Norizul Inayah. Produk dari UD Sumber Rejeki adalah kerupuk spesial ikan payus, ikan bandeng, kerupuk lele, kerupuk bayam lele, kerupuk bayam payus, kerupuk kerang, kerupuk udang, kerupuk buah mangrove, kerupuk buah naga, dan kerupuk jambu merah. Selama proses produksi mitra belum mengetahui tentang pentingnya sanitasi dalam pengolahan makanan termasuk pengolahan kerupuk ikan. Hal ini dikarenakan minimnya pengetahuan tentang penerapan sanitasi makanan pada produksi kerupuk ikan. Proses produksi kerupuk ikan juga belum memenuhi kaidah atau pedoman Cara Produksi Pangan Olahan yang Baik (CPPOB) atau biasa disebut dengan istilah Good Manufacturing Practices (GMP). Hal ini ditunjukkan dengan selama proses produksi mitra tidak memakai baju kerja (apron), topi koki, dan tidak ada persiapan khusus seperti mencuci tangan dan mencuci peralatan sebelum memulai untuk memproduksi kerupuk ikan. Hal lain juga ditunjukkan dari kondisi peralatan yang 
digunakan dalam proses produksi kerupuk ikan yang belum sepenuhnya dipisahkan antara peralatan proses produksi dab peralatan rumah tangga. Kurangnya penerapan sanitasi makanan dapat menyebabkan timbulnya kontaminan pada produk dan dapat mempengaruhi kualitas produk kerupuk ikan.

Pengetahuan tentang sanitasi pengolahan makanan merupakan faktor yang sangat berpengaruh terhadap kualitas makanan yang disajikan kepada konsumen [3]. Standar hidup masyakarat sangat dipengaruhi oleh sanitasi [4]. Produk makanan merupakan produk yang sangat erat kaitannya dengan Kesehatan sehingga harus benar-benar terjada dari kontaminan. Bahan baku yang berupa ikan mempunyai sifat yang sangat rentan terhadap kerusakan. Tingginya kandungan protein $(18-23 \%)$ dan lemak $(0,5$ - 10,0\%) menyebabkan ikan mudah mengalami kebusukan akibat proses oksidasi atau kontaminasi mikroorganisme [5]. Kebersihan diri pada mitra selama proses produksi kerupuk ikan juga menjadi faktor penting terhadap keamanan produk kerupuk ikan, karena manusia dapat juga menjadi sumber kontaminan.

Kegiatan ini bertujuan untuk menerapkan dan meningkatkan prinsip sanitasi makanan pada produksi kerupuk ikan sesuai dengan kaidah atau pedoman Cara Produksi Pangan Olahan yang Baik (CPPOB) atau Good Manufacturing Practices (GMP) [6]. Penerapan prinsip sanitasi makanan menjadi bagian penting dari kaidah tersebut agar tidak terjadi kontaminasi yang menyebabkan gangguan kesehatan akibat makanan.

\section{METODE PELAKSANAAN KEGIATAN}

\section{Kegiatan Program Kemitraan}

Masyarakat (PKM) ini dilakukan di UD Sumber Rejeki sebagai mitra. Tahap pertama pada pelaksanaan PKM ini adalah melakukan koordinasi dengan mitra untuk persiapan kegiatan dari awal sampai akhir. Tahap kedua adalah pelaksanaan kegiatan PKM yang terdiri dari beberapa metode.

Metode pelaksanaan kegiatan PKM ini adalah melakukan sosialisasi, pendampingan, dan edukasi tentang pentingnya penerapan prinsip sanitasi makanan pada produksi kerupuk ikan sesuai dengan CPPOB atau GMP. Metode ini berupa penyampaian materi tentang pentingnya penerapan sanitasi makanan pada produksi kerupuk ikan dan dilakukan diskusi setelah materi selesai disampaikan. Metode lain yang dilakukan pada kegiatan PKM ini adalah membantu pengadaan baju produksi (apron) dan topi koki lengkap dengan desain dan ukurannya, masker, tempat sampah, dan booklet yang berisikan sanitasi diri, bahan baku, peralatan, dan sanitasi ruangan. 
HASIL DAN PEMBAHASAN

Kegiatan Sosialisasi, Pendampingan, dan Edukasi tentang Penerapan Prinsip Sanitasi Makanan pada Produksi Kerupuk Ikan

Kegiatan ini bertujuan untuk memberikan edukasi mitra tentang penerapan prinsip sanitasi makanan pada produksi kerupuk ikan, salah satunya adalah syarat bahan makanan. Beberapa syarat sanitasi makanan adalah bahan makanan yang sehat, bersih, dan segar, proses produksinya baik dan benar, bahan dan campurannya yang benar dan sesuai, tempat dan peralatan produksi makanan yang bersih dan terawat, dan pembuatan hidangan makanan sesuai dengan SOP (Standard Operating Procedure) [7].

Kegiatan ini dilakukan dengan cara memberikan materi tentang penerapan prinsip sanitasi makanan pada produksi kerupuk ikan. Penyampaian materi dikemas dengan sangat menarik. Materi diberikan visualisasi berupa gambar yang menarik dan mudah dipahami oleh mitra. Kegiatan ini disajikan pada Gambar 1.

Pada saat narasumber menyampaikan materi tentang penerapan prinsip sanitasi pada produksi kerupuk ikan mitra terlihat sangat antusias. Hal ini ditunjukkan dengan diskusi yang terjadi secara duah arah antara pemateri dan mitra. Mitra juga memberikan catatan tambahan pada print out materi yang telah dibagikan di saat pemateri menjelaskan.

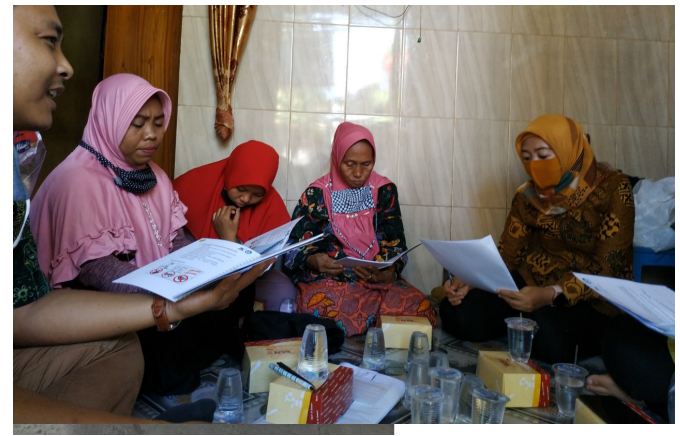

Gambar 1. Kegiatan sosialisasi, pendampingan, dan edukasi tentang penerapan prinsip sanitasi makanan

Mitra juga berkomitmen untuk menerapkan dan meningkatkan sanitasi makanan dan menggunakan peralatan produksi sesuai dengan kaidah СРРОВ atau GMP. Antusiasme mitra ketika ditunjukkan pada Gambar 2.

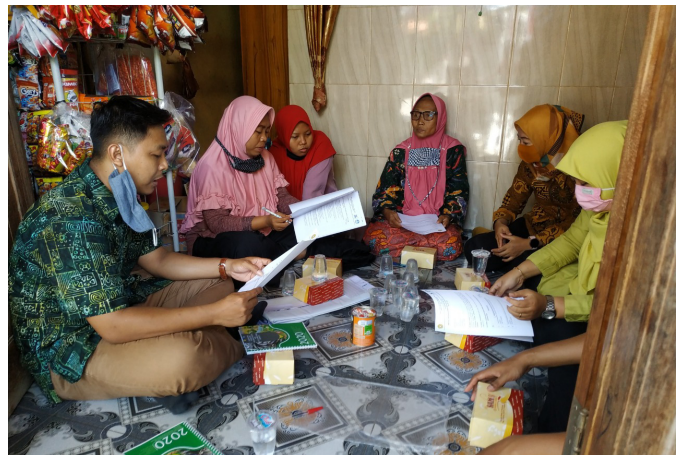

Gambar 2. Antusiasme mitra

Kegiatan pengadaan baju produksi (apron), alat penunjang sanitasi makanan, dan pengadaan booklet

Kegiatan PKM dalam usaha penerapan dan peningkatan sanitasi makanan pada produksi kerupuk ikan didukung dengan adanya pengadaan baju produksi (apron), alat penunjang sanitasi makanan lainnya (topi koki, masker, tempat sampah), dan booklet. Adanya baju produksi, alat penunjang sanitasi makanan, dan booklet menunjukkan bahwa adanya usaha penerapan dan peningkatan sanitasi makanan pada produksi 
kerupuk ikan telah dijalankan oleh UD Sumber Rejeki. Penerapan dan peningkatan sanitasi makanan pada produksi kerupuk ikan UD Sumber Rejeki telah memenuhi kaidah CPPOB atau GMP.

Baju produksi (apron), dan alat penunjang sanitasi makanan pada produksi kerupuk ikan serta booklet tentang sanitasi telah diberikan kepada mitra. Baju produksi (apron) dan topi koki dilengkapi dengan desain dan ukuran desainnya. Desain baju produksi (apron) dan topi koki disajikan pada Gambar 3.

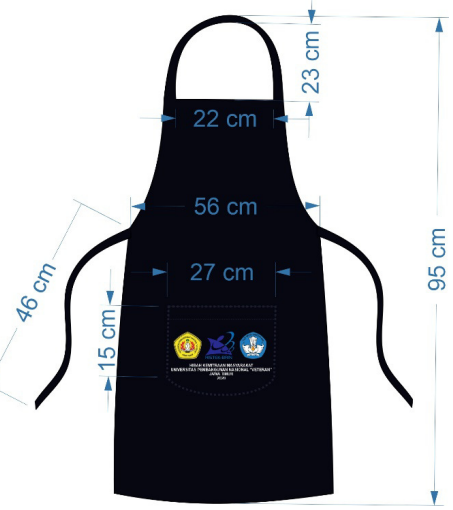

(a)

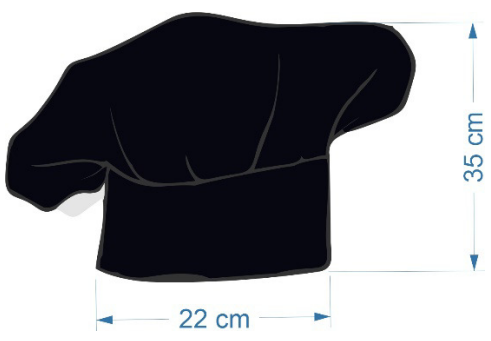

(b)

Gambar 3. (a) desain baju produksi (apron) dan (b) desain topi koki

Alat penunjang sanitasi makanan pada produksi kerupuk ikan seperti masker dan tempat sampah disajikan pada Gambar 4.

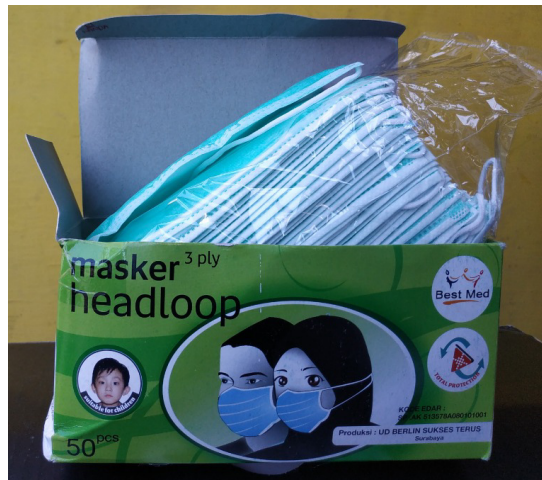

(a)

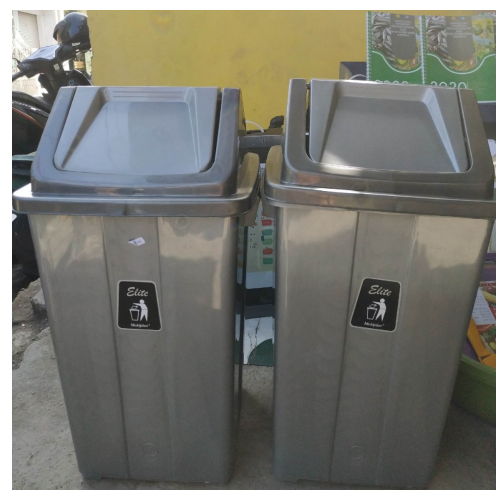

(b)

Gambar 4. Alat penunjang sanitasi makanan: (a) masker, dan (b) tempat sampah

Booklet sanitasi makanan pada produksi kerupuk ikan UD Sumber Rejeki ditunjukkan pada Gambar 5. Booklet tersebut berisikan tentang sanitasi diri, bahan baku, peralatan, dan sanitasi ruangan.

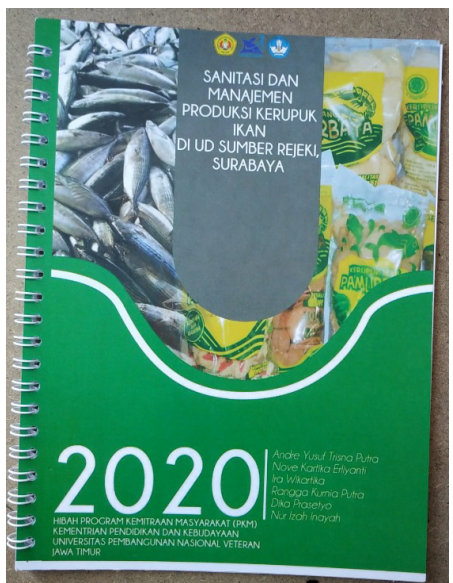

Gambar 5. Booklet sanitasi makanan pada produksi kerupuk ikan UD Sumber Rejeki 
Penyerahan baju produksi (apron), topi koki, masker, tempat sampah, dan booklet sanitasi makanan ke mitra disajikan pada Gambar 6.

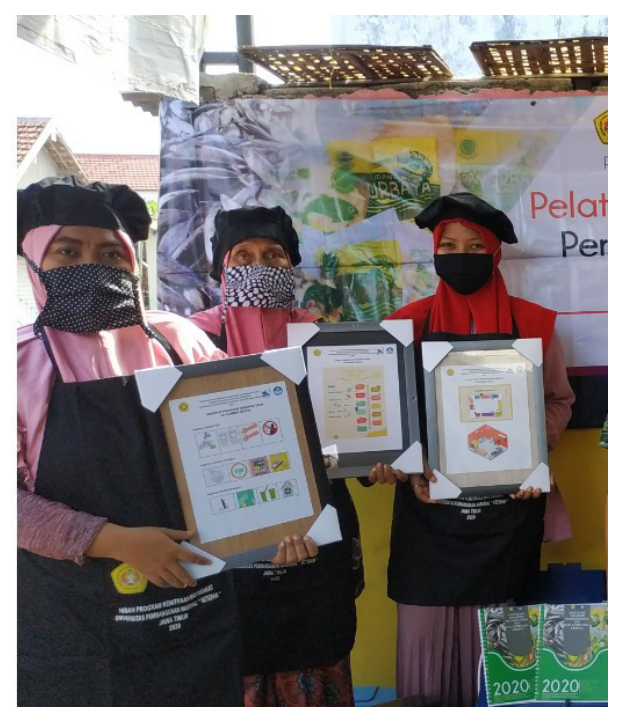

Gambar 6. Penyerahan baju produksi (apron), topi koki, masker, tempat sampah, dan booklet sanitasi makanan ke mitra

\section{KESIMPULAN}

Kesimpulan dari kegiatan PKM ini adalah usaha penerapan dan peningkatan sanitasi makanan pada produksi kerupuk ikan UD Sumber Rejeki sesuai dengan kaidah CPPOB atau GMP telah dilaksanakan dengan baik. Hal ini ditunjukkan dengan antusiasnya mitra ketika narasumber menyampaikan materi dan adanya komitmen dari mitra untuk menerapkan sanitasi makanan. Kegiatan ini dapat menambah wawasan mitra tentang pentingnya penerapan dan peningkatan sanitasi makanan. Baju produksi, alat penunjang, dan booklet membantu mitra dalam usaha peningkatan sanitasi makanan pada produksi kerupuk ikan UD Sumber Rejei sesuai dengan kaidah CPPOB atau GMP.

\section{SARAN}

Disarankan untuk memberikan edukasi tentang sanitasi dan hygiene peralatan pada proses produksi kerupuk ikan.

\section{UCAPAN TERIMAKASIH}

Tim pengabdian kepada masyarakat mengucapkan terima kasih kepada Direktorat Riset dan Pengabdian Kepada Masayarakat (DRPM), Kementerian Riset dan Teknologi/Badan Riset dan Inovasi Nasional yang telah mendukung dan memberikan dana hibah pengabdian kepada masyarakat pada skim Program Kemitraan Masyarakat (PKM). Tim juga mengucapkan terima kasih kepada UD Sumber Rejeki yang telah bersedia menjadi mitra PKM ini.

\section{REFERENSI}

[1] Badan Pusat Statistik. 2015. Kota Surabaya dalam Angka 2015. https://surabayakota.bps.go.id/publicat ion/2015/10/30/ded0d1f83150c3cbe2f ee327/surabaya-dalamangka2015.html. Diakses pada tanggal 2 September 2019.

[2] Wahida, A. M., Primyastanto, M., and Utami, T. N. 2015. Pengembangan Usaha Kerupuk Ikan Payus (Elops hawaiensis) Pada UD SUmber Rejeki Kelurahan Gunung Anyar Tambak, Kecamatan Gunung Anyar, Kota Surabaya, Jawa Timur. Jurnal ECSOFiM. 3 (1): 40-47.

[3] Sujaya, I. N., Dwipayanti, N. M. U., Sutiari, N. K., and Wulandari, L. P. L. 2009. Pembinaan Pedagang Makanan Kaki Lima untuk Meningkatkan Higiene dan Sanitasi Pengolahan dan Penyediaan Makanan di Desa Penatih, Denpasar Timur. PS. IKM Universitas Udayana. 8-15. [Online]. Available: http://ojs.unud.ac.idabstrak/sujaya090 102010.pdf.

[4] Makotsi, N., Kaseje, D., Mumma, J., Opiyo, J., and Lukorito, L. 2016. 
Association of Community Led Total Sanitation to Reduced Household Morbidity in Nyando District. International Journal of Science Basic and Applied Research. 28 (1): 220230.

[5] Murtini, J. T., Riyanto, R., Priyanto, N., and Hermana, I. 2014. Pembentukan Formaldehid Alami pada Beberapa Jenis Ikan Laut Selama Penyimpanan Dalam Es Curai. JPB Perikanan. 9 (2): 143-151.

[6] Peraturan Menteri Perindustrian RI
No. 75/M-IND/PER/7/2010 tentang Pedoman Cara Produksi Pangan Olahan yang Baik (CPPOB).

[7] Yuliastri, Y., and Yulianto, A. 2013. Peranan Hygiene dan Sanitasi untuk Menjaga Kualitas Makanan dan Kepuasan Tamu di Hotel Inna Garuda Yogyakarta. Jurnal Khasanah Ilmu. 4 (2): 1-17. 